\title{
Game Edukasi Puzzle Pengenalan Alat Musik Tradisional Bali Berbasis Android
}

\author{
I Ketut Herry Saptiawan ${ }^{1}$, I Gede Suardika², I Made Rudita ${ }^{3}$ \\ ${ }^{1,2,3}$ Prodi Sistem Informasi, Fakultas Informatika dan Komputer, Institut Teknologi dan Bisnis STIKOM Bali \\ ${ }^{1}$ herrysaptiawan@gmail.com, ${ }^{2}$ suardika@stikom-bali.ac.id*, ${ }^{3}$ ruditalengar@yahoo.co.id
}

\begin{abstract}
Educational puzzle games can be used as an educational media that can be used as a learning media. This educational puzzle game is implemented in the Educational Puzzle Game for the Introduction of Balinese Traditional Musical Instruments based on Android, so that it can provide users with knowledge and understanding in getting to know Balinese traditional musical instruments as well as playing games. The purpose of this research is to design and build an Educational Puzzle Game for The Introduction of Balinese Traditional Musical Instruments Based on Android. In making this application using the Multimedia Development Life Cycle (MDLC) method. To test educational games in terms of functionality, as well as to test games in terms of usability using the System Usability Scale (SUS) method. From the results of this study, it is hoped that it will be useful for the community in getting to know traditional Balinese musical instruments.
\end{abstract}

Keywords: Educational Puzzle Games, Balinese Traditional Musical Instruments, Android

\begin{abstract}
Abstrak
Game edukasi puzzle merupakan game yang bersifat menghibur dan di dalamnya mengandung pengetahuan yang dapat disampaikan kepada penggunanya. Game edukasi puzzle dapat digunakan sebagai salah satu media pendidikan yang bisa digunakan sebagai media pembelajaran. Game Edukasi Puzzle ini diterapkan di dalam aplikasi Game Edukasi Puzzle Pengenalan Alat Musik Tradisional Bali Berbasis Android, sehingga dapat memberikan pengetahuan dan pemahaman pengguna dalam mengenal alat musik tradisional Bali sekaligus dapat bermain game. Tujuan dari penelitian ini adalah merancang dan membangun sebuah Game Edukasi Puzzle Pengenalan Alat Musik Tradisional Bali Berbasis Android. Dalam pembuatan aplikasi ini mengunakan metode Multimedia Development Life Cycle (MDLC). Untuk menguji game edukasi dari sisi fungsionalitas, serta untuk menguji game dari sisi usability dengan menggunakan metode System Usability Scale (SUS). Dari hasil penelitian tersebut diharapkan berguna bagi masyarakat dalam mengenal alat musik tradisional Bali.
\end{abstract}

Kata kunci: Game Edukasi Puzzle, Alat Musik Tradisional Bali, Android.

\section{Pendahuluan}

Alat musik tradisional adalah alat-alat musik yang lahir dan berkembang di daerah atau wilayah tertentu dan dilestarikan secara turun-temurun dari satu generasi ke generasi berikutnya. Alat musik tradisional dapat dijadikan identitas suatu daerah di Indonesia. Setiap daerah di Indonesia memiliki alat musik tradisionalnya masing-masing, salah satu contoh alat musik tradisional Bali. Alat musik tradisional Bali sebenarnya memiliki beberapa kesamaan dengan alat musik tradisional dari daerah-daerah lainnya di Indonesia. Alat musik tradisional Bali beragam, namun kurangnya pengetahuan dan pengenalan alat musik tradisional Bali tersebut menjadi masalah untuk semua generasi. Untuk mengatasi masalah tersebut dibuatkanlah sebuah media edukasi yang disajikan melalui smartphone, salah satu contohnya yaitu sebuah game edukasi. Game edukasi merupakan salah satu jenis game yang tidak hanya bersifat menghibur tetapi di dalamnya mengandung pengetahuan yang disampaikan kepada penggunanya. Game edukasi dapat digunakan sebagai salah satu media pendidikan yang bisa digunakan sebagai media pembelajaran. Game jenis ini biasa digunakan untuk mengajak penggunanya sambil bermain. Melalui proses belajar ini maka penggunanya dapat memperoleh ilmu pengetahuan, sehingga game edukasi merupakan terobosan terbaru yang digunakan dalam dunia pendidikan. Selain dikarenakan game jenis ini memadukan antara sisi belajar dan bermain, game jenis ini juga dapat digunakan menarik perhatian pengguna untuk belajar [1].

Penelitian yang dilakukan sebelumnya oleh Fahmi Rahim pada tahun 2016. Penelitian ini mengarah pada alat musik tradisional yang ada di Indonesia dan genre game yang digunakan yaitu genre puzzle yang berupa tebak gambar dan tebak kata [2]. Sehingga penulis ingin menerapkan pada penelitian ini yang hanya berfokus pada daerah Bali saja dan dengan menggunakan genre puzzle yang berupa pecahan gambar yang diacak dan disusun kembali menjadi utuh, dan game puzzle ini menggunakan platform Android. Dengan menggunakan genre puzzle ini, diharapkan mampu melatih kemampuan otak dan mengasah otak. Selain itu, game puzzle juga dapat mengandung tantangan yang bersifat membuat pengguna penasaran.

Android merupakan sistem operasi open source untuk perangkat mobile yang sekarang ini sedang populer, oleh karena itu dipilih sebagai platform dalam pembuatan game edukasi ini. 


\section{Metode Penelitian}

Metode yang digunakan pada Game Edukasi Puzzle Pengenalan Alat Musik Tradisional Bali Berbasis Android ini yaitu metode Multimedia Development Life Cycle (MDLC). Metode ini memiliki 6 tahapan, yaitu Concept, Design, Material Collecting, Assembly, Testing dan Distribution.

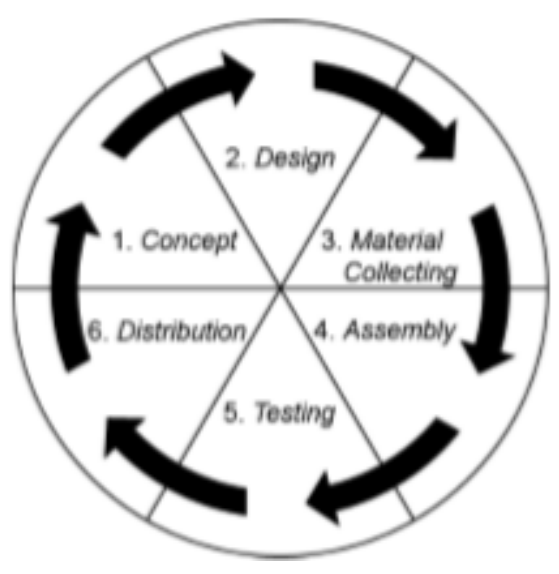

Gambar 1. Metode MDLC
Alat Musik Tradisional Bali Berbasis Android yang akan dijawab oleh responden.

Pada tahap Distribution, pendistribusian dilakukan untuk penyebaran dan penyampaian produk ke pengguna dari aplikasi yang telah selesai dibuat dan telah melalui pengujian. Pendistribusian Game Edukasi Puzzle Pengenalan Alat Musik Tradisional Bali Berbasis Android ini melalui link Google Drive.

\section{Hasil dan Pembahasan}

Dalam bab ini membahas mengenai hasil dan pembahasan dari perancangan sistem yang telah dibuat sebelumnya. Adapun hasil dari perancangan tersebut dijelaskan sebagai berikut.

Hasil analisa $5 \mathrm{~W}+1 \mathrm{H}$ dalam penelitian ini adalah sebagai berikut.

What - Aplikasi tentang apa yang dibuat? Aplikasi yang dibuat adalah aplikasi Game Edukasi Puzzle dimana aplikasi ini memperkenalkan alat musik tradisional Bali yang berisi penjelasan beserta suara dari masing-masing alat musik yang dibuat dalam bentuk game puzzle.

Why - Mengapa aplikasi ini dibuat? Aplikasi ini dibuat untuk memberikan pengetahuan dan pemahaman pengguna dalam mengenal alat musik tradisional Bali.

Who - Untuk siapa aplikasi ini dibuat? Aplikasi ini dbuat untuk semua kalangan usia.

Where - Dimana aplikasi ini bisa diimplementasikan? Aplikasi ini bisa diimplementasikan di perangkat Android dengan versi minimal 4.4 (KitKat).

When - Kapan aplikasi ini dapat diimplementasikan? Aplikasi ini dapat diimplementasikan kapan saja asalkan sudah menginstall aplikasi ini diperangkat Android.

How - Bagaimana aplikasi ini dibuat? Aplikasi ini dibuat dengan beberapa software yaitu: Unity 3D versi 2019.4.11.f1, Adobe Illustrator CC 2018, Adobe multimedia dibuat. Pembuatan aplikasi ini didasarkan Photoshop CC 2018, Microsoft Visual Studio 2019. pada tahap design.

Testing merupakan tahap pengujian apliksi yang telah dibuat. Pengujian sistem menggunakan Black Box Testing dan System Usability Scale (SUS). Black Box Testing dilakukan untuk menguji fungsional yang ada didalam aplikasi apakah sesuai dengan yang diharapkan. Pengujian SUS merupakan pengujian yang berisikan 10 pertanyaan mengenai Game Edukasi Puzzle Pengenalan
Struktur menu merupakan bentuk desain yang akan digunakan dalam pembuatan Game Edukasi Puzzle Pengenalan Alat Musik Tradisional Bali Berbasis Android. Pada tahap ini akan ditentukan menu apa saja yang terdapat dalam aplikasi dan akan dijadikan acuan akhir terhadap pembuatan dari Game Edukasi Puzzle ini. Berikut merupakan desain menu dari Game Edukasi Puzzle Pengenalan Alat Musik Tradisional Bali Berbasis Android. 


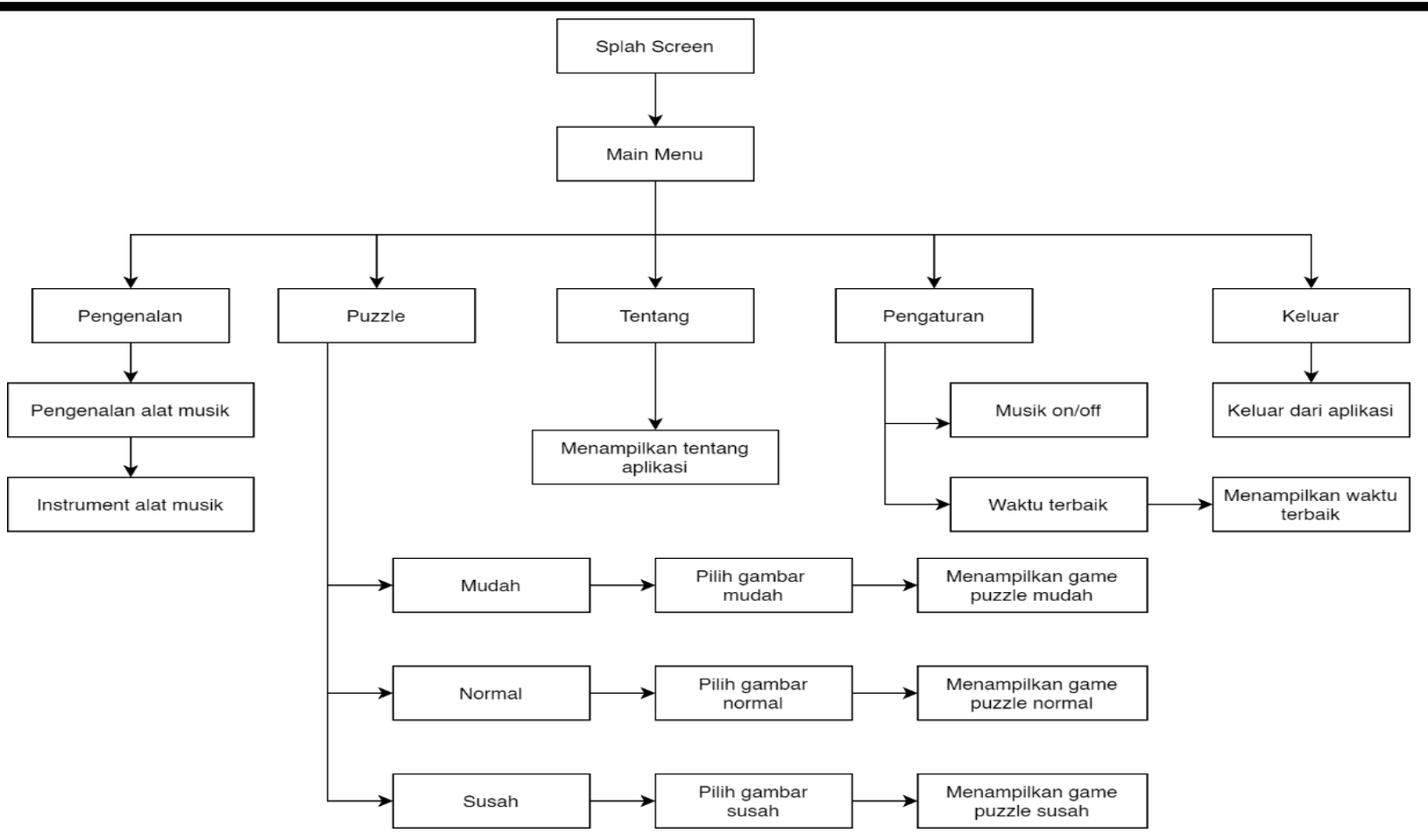

Gambar 2. Struktur Menu

Flowchart umum aplikasi menjelaskan alur, ketika user menu. Main menu terdiri dari Menu Pengenalan, Menu membuka aplikasi, sistem akan menampilkan splash Puzzle, Menu Tentang, Tombol Pengaturan, dan screen dan menampilkan halaman awal. Pada menu Tombol Keluar. Berikut flowchart umum aplikasi dapat utama user dapat memilih semua menu yang ada di main dilihat pada Gambar 3.

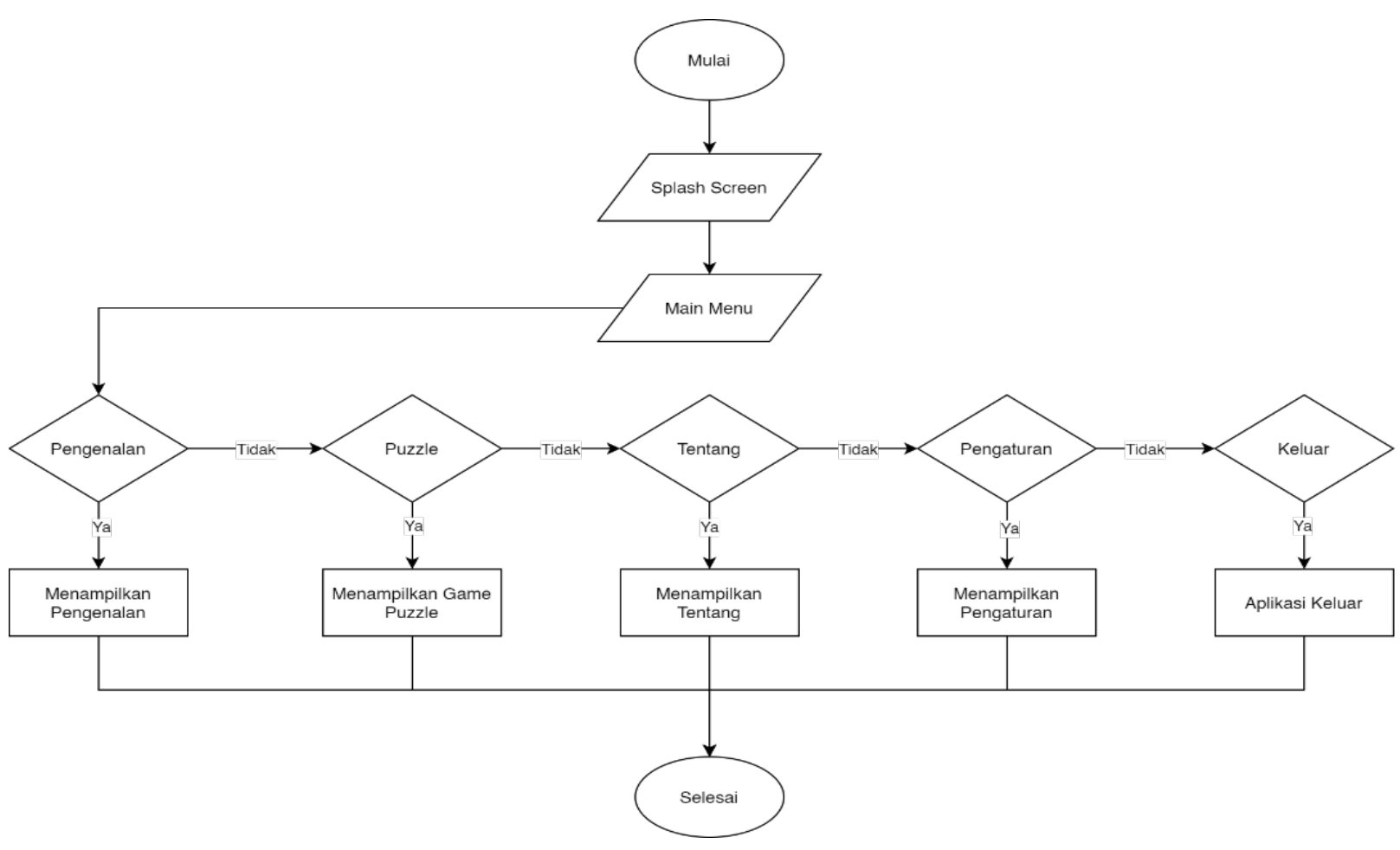


Gambar 4 adalah tampilan halaman Main Menu sebagai halaman utama pada aplikasi. Pada antarmuka ini menampilkan tiga menu yaitu menu Pengenalan yang berisi tentang pengenalan dari alat musik, menu Puzzle yang berisi game puzzle, dan menu Tentang yang berisi penjelasan tentang profil pembuat aplikasi. Pada sisi atas terdapat dua tombol yaitu tombol pengaturan untuk mendrop down menu pengaturan yang dapat dilihat pada Gambar 5, dan tombol keluar untuk menutup aplikasi.

Gambar 5 adalah tampilan Main Menu ketika tombol Pengaturan di klik oleh user. Di tombol Pengaturan ini terdapat dua tombol yaitu tombol musik untuk mematikan/menghidupkan musik background, dan terdapat tombol Waktu Terbaik untuk melihat waktu terbaik dalam game puzzle.

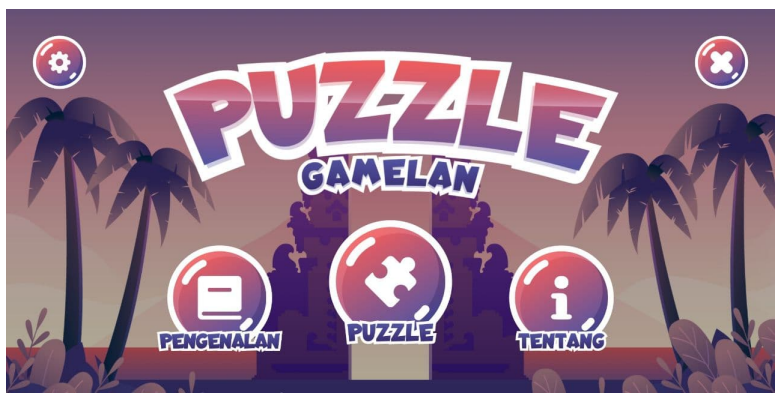

Gambar 4. Tampilan Main Menu

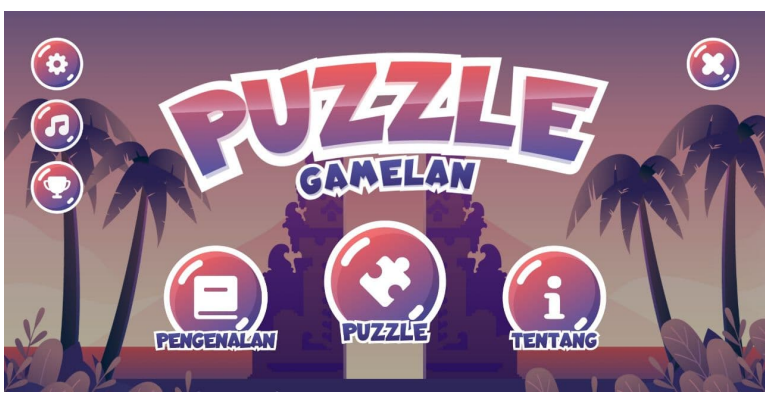

Gambar 5. Tampilan Main Menu (Pengaturan Drop Down)

Gambar 6 merupakan tampilan menu Pengenalan. Halaman ini terdapat tombol kembali ke Main Menu pada atas tampilan. Pada menu ini ditampilkan gambar Alat Musik dan sedikit penjelasan, user dapat menggeser slide untuk melihat materi lainnya yang ada. Pada gambar Alat Musik user dapat mengkilk gambar tersebut untuk mendengarkan suara dari masing-masih alat musik yang dapat dilihat pada Gambar 7 .

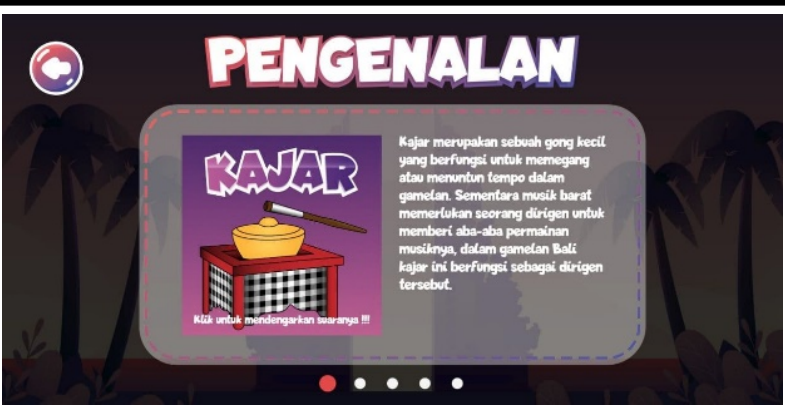

Gambar 6. Tampilan Menu Pengenalan

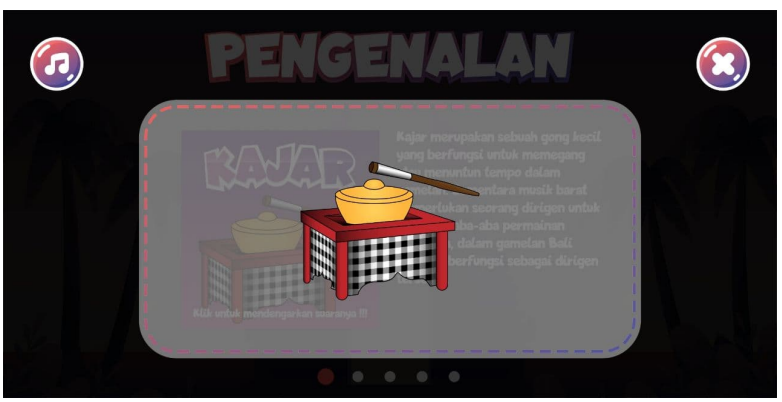

Gambar 7. Tampilan Pengenalan Suara.

Gambar 8. merupakan tampilan awal dari menu Puzzle. Pada menu ini akan ditampilkan pilih level yang bisa dipilih oleh user. Terdapat tiga level yaitu level mudah, level normal, dan level susah. Jika user memilih salah satu level maka akan muncul seperti pada Gambar 9. Pada halaman ini terdapat juga tombol kembali untuk kembali ke Main Menu.

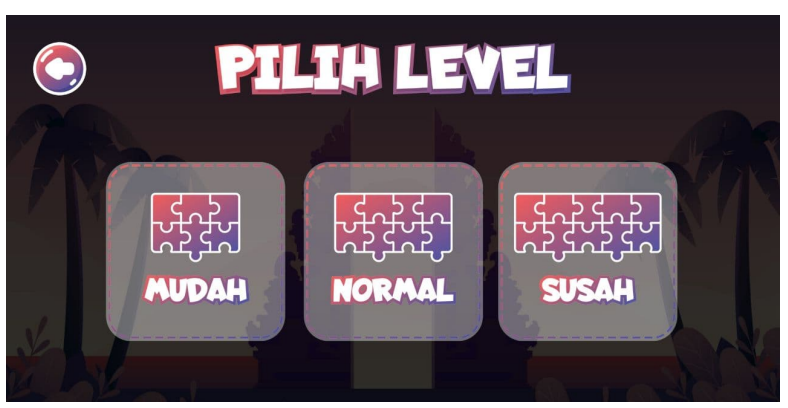

Gambar 8. Tampilan Pilih Level

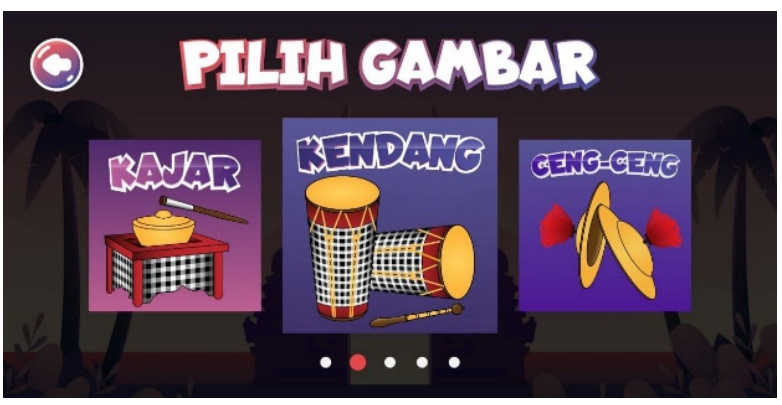

Gambar 9. Tampilan Pilih Gambar 
Gambar 10 merupakan tampilan game puzzle level mudah. Pada halaman ini terdapat game puzzle $3 \times 3$, dipojok atas terdapat waktu terbaik dan waktu dalam memainkan game puzzle dan terdapat tombol pause untuk menjeda game yang sedang berjalan.

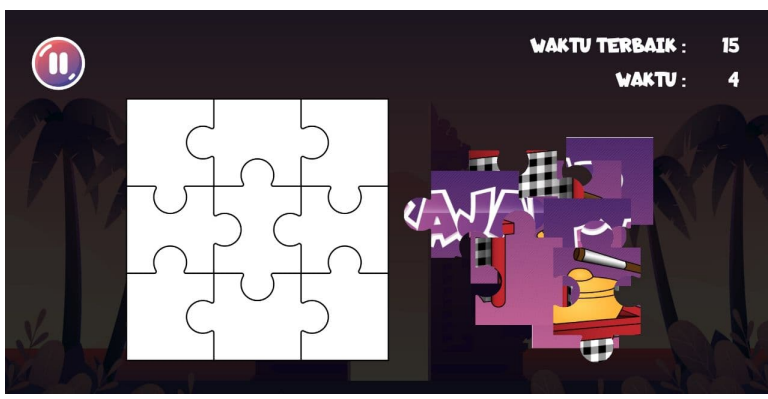

Gambar 10. Tampilan Game Puzzle Level Mudah

Gambar 11 merupakan tampilan game puzzle level normal. Pada halaman ini terdapat game puzzle $4 \times 4$, dipojok atas terdapat waktu terbaik dan waktu dalam memainkan game puzzle dan terdapat tombol pause untuk menjeda game yang sedang berjalan.

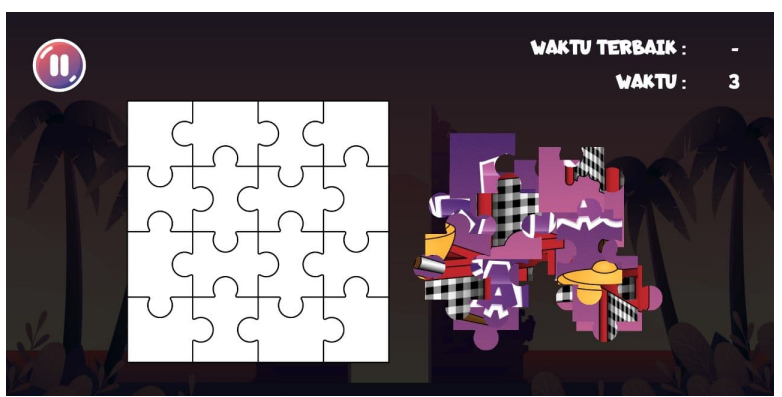

Gambar 11. Tampilan Game Puzzle Level Normal

Gambar 12 merupakan tampilan game puzzle level susah. Pada halaman ini terdapat game puzzle $5 \times 5$, dipojok atas terdapat waktu terbaik dan waktu dalam memainkan game puzzle dan terdapat tombol pause untuk menjeda game yang sedang berjalan.

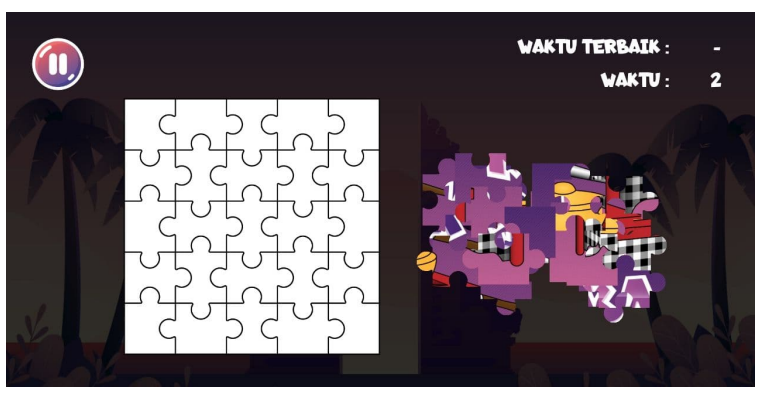

Gambar 12. Tampilan Game Puzzle Level Susah

Gambar 13 merupakan tampilan ketika puzzle selesai. Ketika puzzle telah diselesaikan maka akan muncul PopUp berhasil dan terdapat waktu terbaik dan waktu Drive dan dapat di download melalui short link pada saat memainkan game puzzle. Pada tampilan https://bit.ly/PuzzleGamelan.

PopUp ini juga terdapat tombol pilih gambar dan tombol home untuk kembali ke main menu.

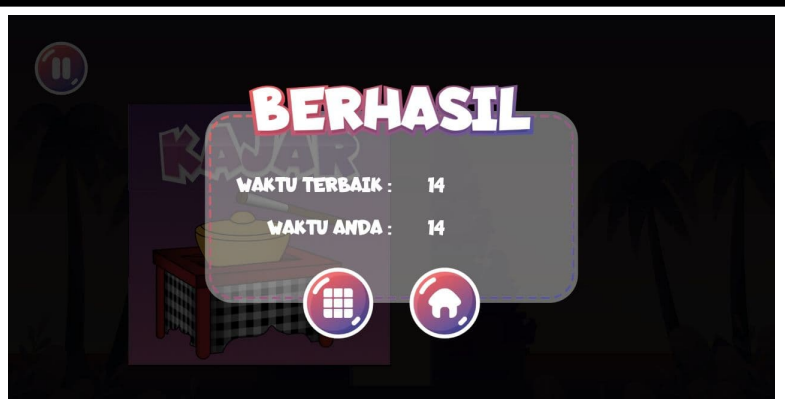

Gambar 13. Tampilan Pop Up Selesai

Setelah aplikasi berhasil dijalankan, pengujian perlu dilakukan untuk memastikan aplikasi berfungsi dengan benar. Pengujian yang digunakan dalam menguji aplikasi ini adalah Black Box Testing dan Kuesioner dengan metode System Usability Scale (SUS).

Pengujian dengan metode Black Box Testing sendiri merupakan suatu metode pengujian perangkat lunak dimana struktur internal atau desain maupun implementasi item yang diuji tidak diketahui oleh penguji. Tes ini dapat diketahui berfungsi atau tidaknya suatu perangkat lunak tersebut. Pengujian ini dilakukan dengan cara memamasukan data dan melihat luaran dari aplikasi apakah sudah sesuai dengan yang diharapkan atau tidak. Berdasarkan pengujian yang telah dilakukan, Game Edukasi Puzzle Pengenalan Alat Musik Tradisional Bali Berbasis Android dapat berjalan dengan lancar dan baik sesuai dengan rancangan.

System Usability Scale (SUS) merupakan kuesioner untuk mengukur persepsi kegunaan. SUS diciptakan oleh John Brooke pada tahun 1986 dan dahulu digunakan untuk menguji sitem elektronik kantor. SUS terdiri dari 10 pertanyaan dan masing-masing pertanyaan memiliki 5 poin yang menggunakan skala Likert sebagai tanggapan. Output SUS berupa skor dengan range dari 0 hingga 100 , semakin besar skor berarti semakin baik usability-nya. Berdasarkan pengujian yang telah dilakukan, Game Edukasi Puzzle Pengenalan Alat Musik Tradisional Bali Berbasis Android mendapat skor rata-rata SUS adalah " 80,17 ", maka skor tersebut masuk dalam kategori "Good" dengan grade scale "B". Secara usabillity, dapat disimpulkan bahwa Game Edukasi Puzzle Pengenalan Alat Musik Tradisional Bali Berbasis Android layak untuk digunakan.

Pendistribusian aplikasi Game Edukasi Puzzle Pengenalan Alat Musik Tradisional Bali Berbasis Android merupakan tahap terakhir dimana setelah aplikasi telah melalui serangkaian perancangan, pembangunan dan pengujian, dan pada tahap ini aplikasi siap untuk didistribusikan. Aplikasi Game ini akan di terbitkan dalam bentuk format apk yang dapat dijalankan pada perangkat smartphone berbasis android. 


\section{Kesimpulan}

Dari hasil perekayasaan yang telah dilakukan, maka diperoleh beberapa kesimpulan sebagai berikut. Pada penelitian ini telah berhasil dirancang dan dibangun sebuah aplikasi Game Edukasi Puzzle Pengenalan Alat Musik Tradisional Bali Berbasis Android dengan menggunakan Multimedia Development Life Cycle (MDLC). Dari hasil pengujian dengan metode Black Box dapat disimpulkan bahwa aplikasi dapat berjalan dengan lancar dan baik sesuai dengan rancangan. Berdasarkan hasil pengujian yang telah dilakukan oleh 30 responden didapatkan skor rata-rata SUS adalah "80,17" yang masuk dalam kategori "Good" dengan grade scale "B". Secara usabillity, dapat disimpulkan bahwa Game Edukasi Puzzle Pengenalan Alat Musik Tradisional Bali Berbasis Android layak untuk digunakan dan dipublikasikan.

\section{Daftar Rujukan}

[1] I. N. Sari, "Rancang Bangun Aplikasi Game Edukasi Pakaian Adat Suku Batak 'Ulos' Pada Platform Android," Univ. Udayana, 2015.

[2] F. Rahim, "Game Edukasi Pengenalan Alat Musik Tradisional di Indonesia Berbasis Android," Univ. Islam Negeri Alauddin Makassar, 2016.
[3] I. Rohmawati, "Pengembangan Game Edukasi Tentang Budaya Nusantara 'Tanara' Menggunakan Unity 3D Berbasis Android,' J. SITECH Sist. Inf. dan Teknol., vol. 2, no. 2, pp. 173-184, 2019.

[4] D. Damayanti, M. F. Akbar, and H. Sulistiani, "Game Edukasi Pengenalan Hewan Langka Berbasis Android Menggunakan Construct 2," J. Teknol. Inf. dan Ilmu Komput., vol. 7, no. 2, pp. 275-282, 2020.

[5] W. Pratama, "Game Adventure Misteri Kotak Pandora," J. Telemat., vol. 7, no. 2, pp. 13-31, 2014.

[6] H. Kusniyanti and N. S. P. Sitanggang, "Aplikasi Edukasi Budaya Toba Samosir Berbasis Android," Tek. Inform., vol. 9, no. 1, pp. 9-18, 2016.

[7] S. L. B. Ginting and F. Sofyan, "Aplikasi Pengenalan Alat Musik Tradisional Indonesia Menggunakan Metode Based Marker Augmented Reality Berbasis Android," Maj. Ilm. UNIKOM, vol. 15, no. 2, pp. 139-154, 2017.

[8] I. M. Bandem, Gamelan Bali Di Atas Panggung Sejarah. Badan Penerbit STIKOM BALI, 2013.

[9] M. I. Hanafri, A. Budiman, and N. A. Akbar, "Game Edukasi Tebak Gambar Bahasa Jawa Menggunakan Adobe Flash CS6 Berbasis Android," J. Sisfotek Glob., vol. 5, no. 2, pp. 50-53, 2015.

[10]A. R. Dewi, R. R. Isnanto, and K. T. Martono, "Aplikasi Multimedia sebagai Media Pembelajaran Ilmu Pengetahuan Sosial Materi Budaya di Indonesia menggunakan Unity Engine untuk Sekolah Dasar,” J. Teknol. dan Sist. Komput., vol. 3, no. 4, pp. 471-480, 2015.

[11]J. Enterprise, Panduan Adobe Illustrator. PT Elex Media Komputindo, 2020.

[12]A. Hartoko, Paket Lengkap Photoshop. PT Elex Media Komputindo, 2020. 